\title{
The turn of 1918 and 1919 in Lithuania in the light of unknown documents
}

Zarys treści: Dzięki nieznanym dotąd, unikalnym dokumentom odnalezionym w dwóch moskiewskich archiwach (Архив внешней политики Российской империи; Российский государственный военный архив), pisanym na przełomie 1918 і 1919 roku przez przedstawicieli dwóch stron polsko-sowieckiego frontu autorka omawia sytuację w Wilnie na przełomie grudnia 1918 i stycznia 1919 roku.

Content outline: Thanks to previously unknown documents found in two Moscow archives (Archive of the Foreign Policy of Imperial Russia and Russian State Military Archive), written at the turn of 1918 and 1919 by representatives of two sides of the Polish-Soviet front, the author discusses the situation in Vilnius at the turn of December 1918 and January 1919.

Slowa kluczowe: Litwa 1918-1919, Wilno, wojna polsko-sowiecka 1920, bolszewicy, Bund, Wileńska Samoobrona, Litwini, Żydzi, Polacy, Białorusini

Keywords: Lithuania 1918-1919, Vilnius, Polish-Soviet war 1920, Bolsheviks, Bund, Vilnius Self-Defence, Lithuanians, Jews, Poles, Belarusians

The extensive historical literature on Vilnius and Lithuania of the first decades of the $20^{\text {th }}$ century contains a significant gap. Basically, there are no period sources detailing what happened there from November 1918 to April 1919. ${ }^{1}$ Owing to hitherto unknown documents found in two Moscow archives, which are, importantly, documents written at the turn of 1918 and 1919 by representatives of

${ }^{1}$ Our main source of information is Boleslaw Waligóra's work, dedicated primarily to the military aspect of the subject: Walka o Wilno Okupacja Litwy i Bialorusi w 1918-1919 przez Rosje Sowiecka, Wilno, 1938. In addition to the press releases, some information is also brought by the Report of General Wojciech Falewicz (1863-1935), who was head of the Military and Geographical Institute from 19 December 1918 to 12 April 1919. On 13 April 1919, he assumed the duties of Commander of the Grodno Fortress. A copy is kept at the RGVA Fond 471K-2-11 fol. $20-20 \mathrm{v}$. 
the opposite sides of the Polish-Soviet front, we are now able to fill this gap in our knowledge.

The subject of this study is the content of several documents uncovered in Moscow. The collection of the Russian Central State Military Historical Archive (Rossiyskiy gosudarstvennyy voyennyy arkhiv, Trofeynyy Fond) contains materials of the Supreme Command of the Polish Army (Naczelne Dowództwo Wojska Polskiego, NDWP). This includes seven reports/information releases of 1 January and 21 January as well as 3, 10, 19, 24 and 25 February 1919:

1) Raport Informacyjny wojskowy z dnia 1 stycznia 1919 roku [Military Information Report of 1 January 1919]. Sztab Generalny WP 1./VI./1. [Polish General Staff 1./VI./1.] Oddział VI Wschód. [Department VI East] [Akapit (section)] Litwa. [Lithuania ${ }^{2}$

2) Komunikat Informacyjny z dnia 21 I 1919 [Information Notice of 21 January 1919] [Akapit] Grodno. Sztab Generalny WP Tajne [Top secret]. nr. 592/VI/7. Oddz. VI Wojskowy. [Department VI Military $]^{3}$

3) Wojskowy Komunikat Informacyjny z dnia 3 II 1919 [Military Information Notice of 3 February 1919] [Akapit] Wilno. [Vilnius] Sztab Generalny WP Poufne [Confidential] Nr 933/VI/10 Oddz. VI. ${ }^{4}$

4) Raport Informacyjny Wojskowy z dnia 10 II 1919. Wschód. Sztab Generalny WP nr 1114/VI/12 Oddz. VI. [Akapit] Wojska niemieckie na Wschodzie [German troops in the East]. ${ }^{5}$

5) Raport Informacyjny Wojskowy z dnia 19 II 1919. Sztab Generalny W.P. Tajne 1396/VI/16 O VI. ${ }^{6}$

6) Raport Informacyjny Wojskowy z dnia 24 II 1919. NDWP [Supreme Command of the Polish Army] Sztab Generalny Nr 1689/VI O VI.?

7) Raport Informacyjny Wojskowy z dnia 25 II 1919. Sztab Generalny W.P. 1699/VI/18 O. VI ${ }^{8}$

The Foreign Policy Archive in Arbat in Moscow (hereinafter: AVP) contains, among others, the following (in one file):

1) "Komunikat" [Communiqué] (only the first page) dated "6 I 1919, pt. 2" addressed to "Moskva Metropol Narkominodel Chicherinu, kopia Inorosta gazeta" and

2 Russian State Military Archive in Moscow [Rossiyskiy gosudarstvennyy voyennyy arkhiv] (hereinafter: RGVA) Fond $471 \mathrm{~K}-2$ - fol. 17-17v.

3 RGVA Fond $308 \mathrm{~K}-9$ - 582 fol. 15-19.

${ }^{4}$ RGVA Fond $308 \mathrm{~K}-9$ - 582 fol. $37-39$.

${ }^{5}$ RGVA Fond $308 \mathrm{~K}-9$ - 582 fol. $44-48$.

${ }^{6}$ RGVA Fond $308 \mathrm{~K}-9$ - -582 fol. 80-85.

7 RGVA Fond 308K - 9 - 582 fol. 105-113.

8 RGVA Fond 308K - 9 - 582 fol. 114-117.

9 Foreign Policy Archive [Arkhiv Vneshney Politiki] (hereinafter: AVP) Referentura po Litwie. Fond [0]151 op. 2 p. 1 d. 10 fol. 16. 
2) "Zapiska Gopnera o polozhenii na Litve sostavlena 15-go yanvarya 1919 g." [Gopner's note on the situation in Lithuania compiled on 15 January 1919]. ${ }^{10}$

The place of storage of the last two documents produced by the Soviet/Russian side is sadly the reason why traditional source editing is impossible here. The internal regulations of the Foreign Policy Archive do not authorise the copying and publication of reports produced by the Russian side, but instead do permit the examination of the content of the materials found in this archive. For this reason, the present text needs to follow an essay format, and precise references to the place of storage of both Russian documents are only provided at the beginning of this article.

In order to evoke the unique style of the period, the text is inlaid with numerous quotes, mainly from the extensive 18-page typescript of the Russian report, i.e. "Zapiska Gopnera o polozhenii na Litve sostavlena 15-go yanvarya 1919 g."

The presented sources differ significantly not only in terms of volume. The military reports of the Sixth Department of the Polish General Staff are, of course, a very valuable source. However, the value of the documents produced by the Russian side is truly exceptional. Their author, a representative of the new Soviet government, describes Vilnius as he is already operating there, and incidentally in his "Note of 15 January" he draws comparisons with his own observations made during his first stay in the city in 1904. Thus, Gopner's extensive report from Vilnius of 15 January 1919 is of twofold value. It represents an account of the current state, supplemented by comparisons with the situation and political circumstances in the city 15 years earlier. The description of the people and territories that the new Soviet authorities found after the retreat of the Germans is priceless. Another advantage of Gopner's report is the opportunity to observe the beginnings of the formation of a new authority in the territory of Eastern Europe.

Gopner had a penchant for economics. A separate study by Gopner can be found in the Ukrainian fond: an analysis of economic ties between Ukraine and Russia in the years 1918-1919. Aside from military and political issues, the note of 15 January also devotes extensive and important passages to matters of economy, industry, trade and rural work organisation.

Information on military movements in the Lithuanian territory in December 1918 is contained both in the Russian "Communiqué" dated "6 January 1919, part 2" and addressed to Chicherin, as well as on the first two pages of the Polish Military Information Report (1./VI./1.) 1 January 1919, penned by an undisclosed officer of the Sixth Department of the Polish General Staff. ${ }^{11}$ The authors of the

\footnotetext{
10 AVP Referentura po Litwie. Fond [0]151 op. 2 p. 1 d. 10 fol. 17-34 (internal numbering of report 1-18).

11 RGVA Fond $471 \mathrm{~K}-2$ - 11 fol. $17-17 \mathrm{v}$.
} 
subsequent Polish military reports cited in the text, dated 21 January to 25 February 1919, are not known either. ${ }^{12}$

The author of two Russian reports from Vilnius of 6 and 15 January 1919 (Komunikat and Zapiska) is, on the other hand, known. ${ }^{13}$ It is David Yulevich Gopner, born in Kherson in 1884, and deceased in $1925 .{ }^{14}$

\section{Who was David Yulevich Gopner?}

David Yulevich Gopner is a prominent figure of this period, active in the lands of the former Grand Duchy of Lithuania and Ukraine. The course of his education remains unclear, but his professional skills allowed him to take up the duties of a turner, electrical engineer and finally a bookkeeper. We know a lot more about his political career. Already at the age of 16, he was a member of the Russian Social Democratic Workers' Party (Rossiyskaya sotsial-demokraticheskaya rabochaya partiya, RSDRP), which had been established two years earlier. In 1904 he visited Vilnius for the first time. That same year, at the age of twenty, he was sent to exile, accused by the Tsarist authorities of distributing illegal literature. His name appears in the register of Jews exiled to the Arkhangelsk Governorate. ${ }^{15}$

${ }_{12}$ I am referring here to the reports numbered 1-7 above. RGVA Fond 308K - $9-582$ fol. 15-19, Sztab Generalny WP Tajne. nr 592/VI/7. Oddz. VI Wojskowy Komunikat Informacyjny z dnia 21 I 1919 Grodno; RGVA Fond 308K - 9- 582 fol. 37-39, Sztab Generalny WP Poufne $\mathrm{Nr}$ 933/VI/10 Oddz. VI Wojskowy Komunikat Informacyjny z dnia 3 II 1919 Wilno; RGVA Fond 308K-9-582 fol. 44-48, Sztab Generalny WP nr 1114/VI/12 Oddz. VI Raport Informacyjny Wojskowy z dnia 10 II 1919. Wschód. [Akapit] Wojska niemieckie na Wschodzie; RGWA 308K9-582 fol. 80-85, Sztab Generalny W.P. Tajne 1396/VI/16 O VI Raport Informacyjny Wojskowy z dnia 19 II 1919; RGCA Fond 308K-9-582 fol. 105-113, NDWP Nr Sztab Generalny 1689/VI O VI Raport Informacyjny Wojskowy z dnia 24 II 1919; RGWA Fond 308K-9-582 fol. 114-117, Sztab Generalny W.P. 1699/VI/18 O. VI Raport Informacyjny Wojskowy z dnia 25 II 1919.

13 AVP Fond 151 op.2 p.1 d.10 fol. 16, [David Yulevich Gopner] 6 January 1919 [to:] II Moscow, Metropol. Narkomindel Chicherinu Kopia Inorosta gazeta). Subsequent Gopner's report: AVP Fond 151 op. 2 p.1 d.10 fol. 17-34, "Gopner's note on the situation in Lithuania compiled on 15 January 1919."

${ }^{14}$ David Yulevich Gopner is sometimes confused with Serafima Gopner, a Ukrainian delegate to the International Communist Congress in Moscow (2-6 March 1919), who was four years his senior. Serafima Gopner (1880-1966) was a member since 1905, and later secretary, of the Bolshevik party in Yekaterinoslav. In the years 1910-1917, she lived in emigration. From 9 September to 23 October 1918, she was the secretary of the Communist Party of Ukraine. In the years 1928-1938 she took part in the works of the Comintern. In 1945, she was employed at the Institute of Marxism-Leninism in Moscow.

15 Список евреев, сосланных в Архангельскую губернию в 1904 годуВ написании имен, отчеств и фамилий возможны неточности и искажения, так как список составлен на основе описей архивного фонда канцелярии губернского правления, которые неоднократно переписывались и перепечатывались. http://nataniellahaus.narod.ru/index/spiski_evreev_vyslannykh_v_1904_1906_godakh_v_arkhangelskuju_guberniju/0-96. http://www.lochchilov.com/index/ 
According to all available biographies of Gopner, in the years 1913-1917, he lived "in emigration." He returned to Russia in 1917.

According to some sources, in 1918 he was allegedly appointed head of department at the Ukrainian People's Commissariat for Foreign Affairs (Narkomat zakordonnykh sprav, NKZS). According to Spravochnik po istorii Kommunisticheskoy partii i Sovetskogo Soyuza, 1898-1991, ${ }^{16}$ in January 1919, he acted as a plenipotentiary of the Council of People's Commissars of the RSFSR ${ }^{17}$ before the Council of People's Commissars of the Ukrainian Socialist Soviet Republic and at the Council of People's Commissars of the Lithuanian-Byelorussian Soviet Socialist Republic. Gopner also served as the general consul of the RSFSR in Kharkov. ${ }^{18}$ As a result, we encounter D.Y. Gopner's name in historical literature mainly in relation to his activities on the Ukrainian soil. ${ }^{19}$ If we were to characterise this activity in one sentence, we would have to say that David Gopner was one of the key figures initiating the process of separating the northern regions of Chernigov Land from Ukraine in order to incorporate them into Great Russia. Owing to his activity on the eastern flank of the emerging Soviet Empire, Gopner earned a great deal of trust from Chicherin. ${ }^{20}$

Gopner's later party career was associated with a completely different part of the former Tsarist Empire. In January 1920, he joined the board of the Interior Department of the Turkestani ${ }^{21}$ commission of the All-Russian Central Executive Committee (VTsIK) and the Council of People's Commissars (SNK) of the RSFSR. ${ }^{22}$ From April of that year to July 1921, he was a plenipotentiary of the People's

evrejskaja_ssylka_na_sever_v_1906_godu/0-198. Item 51. Гопнер Давид Иоселевич, распространение нелегальной литературы.

16 http://www.knowbysight.info/GGG/02114.asp

17 Russian Soviet Federative Socialist Republic.

18 Ірина Матяш ,Українська консульська служба 1917-1923 рр. Як державний інститут: становлення,функціонування, персоналіï.http://shron1.chtyvo.org.ua/matiash_iryna/ukrainska_konsulska_sluzhba_19171923_rr_iak_derzhavnyi_instytut_stanovlennia_funktsionuvannia_person.pdf

19 Геннадій Єфіменко [Gennady Efimenko], «28 грудня уряд переїжджає із Суджі до Білгорода»: «українська історія» Білгородщини у XX столітті” http://likbez.org.ua/ua/tag/featured; idem. Слобідська Україна та формування українсько-російського кордону https://history. vn.ua/book/sloboda-ukraine-formation-ukrainian-russian-border/4.php; Yu. N. Tikhonov, The Report of Djemal Pasha to the Soviet Commissar for Foreign Affairs G. V. Chicherin, available at: https://doi.org/10.24411/2541-9056-2017-00014. See also the discussion forum: http://offtop. ru/radimich/v20_559814_5_.php

20 After: Ю. Тихонов, “Афганская война Сталина,” Soklan.ru, available at: soklan.ru/library/ reading.php?id=965\&start=3220, p. 162 .

21 Turkestan (literally the country of the Turks), a region of Central Asia located between Siberia to the north and Tibet, India and Afghanistan to the south, the Caspian Sea to the west and eastern Mongolia and the Gobi Desert to the east.

22 Гопнер, Давид Юльевич (прокурор; уполномоченный ; 1884-1925). “Мы вступаем лишь в первый фазис борьбы за «восточное направление.” Доклад уполномоченного НКИД в Туркестане Д. Ю. Гопнера в ЦК РКП(б) [Текст] : 1920 г. / публ. подгот. Ю. Н. Тихонов // 
Commissariat for Foreign Affairs (NKID) of the RSFSR for Middle Asia. At the same time, he served as a representative of the Executive Office of the Council of International Propaganda in the East and this was probably related to his accession to the RKP(b) KKP, which took place in 1921. In the second half of 1921 he was a counsellor to the RSFSR mission in Tehran [Persia/Iran], and in the second half of 1922 he was an authorised representative of the RSFSR in the Khorezm People's Soviet Republic. ${ }^{23}$ It remains unclear where he sojourned and what he did in 1923, yet we do know that poor health forced him to take a sickness leave. Until 10 March 1924 he remained at disposal of the Central Asia Office of the CC RKP(b), which delegated him to Ashkhabad. From November 1924 until his death, he was a member of the Organisational Bureau of the $\mathrm{CP}(\mathrm{b})$ of Turkmenistan and, at the same time, a member of the Revolutionary Committee of the Turkmen SSR. Concurrently, he acted as Deputy Head of the Revolutionary Legal Bureau of the Committee and Deputy People's Commissar for Justice and Prosecutor General of the Turkmen SSR. ${ }^{24}$

\section{Who held administrative power in Vilnius in the first two decades of the $20^{\text {th }}$ century?}

In the $19^{\text {th }}$ century Vilnius remained under Russian rule. In September 1915, the Germans invaded the city, thus instating the Ober-Ost administration. With their consent and support, the Lithuanian Congress appointed the Taryba National Council in September 1917. The Lithuanians owe the transformation of their non-sovereign independence (11 December 1917) into true independence (16 February 1918) to the mastery in the art of politics of their leaders. The activity of the 14-person Belarusian Council, which was formed almost around the same time, in January 1918, also under inspiration and enormous support from the Germans, did not contribute in any real way to the development of Belarusian statehood. ${ }^{25}$

On 11 November 1918, Augustinas Voldemaras formed the first Lithuanian government in Vilnius. The Prime Minister considered the acquisition of power in

Исторический архив. - 2013. - № 3. - pp. 92-125. - Библиогр. в сносках. - Примеч.: pp. 116-125.

23 In February 1920, the Red Army captured the Khanate of Khiva. On 26 April 1920, the creation of the Khorezm People's Soviet Republic was announced. On 20 October 1923, it was transformed into the Khorezm Socialist Soviet Republic. On 17 February 1925, the Khorezm SSR was dissolved and its territory divided between the Uzbek SSR, the Turkmen SSR and the Karakalpak Autonomous Oblast.

${ }^{24}$ After: Ю. Тихонов, ор. cit., p. 162.

${ }^{25}$ For more on this subject, see: J. Gierowska-Kałłaur, "Polacy z guberni północno-zachodnich (białoruskich) wobec idei odbudowy niepodległej Polski oraz białoruskich idei niepodległościowych," Polacy na Białorusi od końca XIX do początku XXI wieku, vol. 2, ed. Tadeusz Gawin, Warszawa, 2018, pp. 77-98. 
the historical capital of the Lithuanian nation as a matter of the utmost urgency, and thus it became a priority task of the Lithuanian government. However, the task was not feasible. In 1918, Vilnius was in fact a Polish-Jewish city, while Lithuanians and Belarusians constituted a marginal minority, as evidenced by all censuses, whether Russian or German. ${ }^{26}$ The 1897 Russian census reported only 3,238 Lithuanians in this city, which constituted $2 \%$ of the total population. ${ }^{27}$ The diocesan census of September 1908 showed 2,229 Lithuanians, which constituted $1.26 \%$. The 1909 police census ${ }^{28}$ reported 2,453 Lithuanians, which amounted to $1.20 \%$. The ecclesiastical census of 1908 , corrected in 1912 at the request of the church authorities, showed 2,751, which constituted $1.56 \%$ of the total population. Even the Lithuanian Calendar for the year $1916^{29}$ included the number of 3,671 Lithuanians, which accounted for $2.68 \%$ of the city's population. The German census conducted on 9-11 March 1916 showed 3,699 Lithuanians in Vilnius, which constituted $2.6 \%$ of the inhabitants. ${ }^{30}$ Another German census conducted by the Vilnius food supply bureau ${ }^{31}$ between 4 December 1916 and 10 January 1917 showed 2,909 Lithuanians, or $2.1 \%$ of the total population. The census announced for February 1918 in the whole of "Verwaltung Litauen" was cancelled at the request of the Lithuanian Council. Three weeks after the end of the First World War, on 8 December 1918, Vilnius was proclaimed the capital of Soviet Lithuania by Lithuanian Communist Vincas Mickevičius-Kapsukas. ${ }^{32}$

26 The results of the census ordered by the Germans were announced in March 1916. "Wilno Kreis" was inhabited by 56,632 Poles, 559 Belarusians, 2,713 Lithuanians, and 2,711 Jews, while "Wilno Stadt" by 70,629 Poles, 1,917 Belarusians, 3,699 Lithuanians, and 61,345 Jews. May 1919, comp. by M. Świechowski. Based on German censuses. Another census conducted between 14 December 1916 and 10 January 1917 showed that there were 74,466 Poles, 57,516 Jews, 2,909 Lithuanians, 811 Belarusians, 2,212 Russians, 880 Germans and 193 representatives of other nations in Vilnius.

2747,795 Poles were reported in the city $=31.9 \%$. In the police census: 77,500 or $37.75 \%$; in the Lithuanian calendar census: 68,687 or $50.16 \%$. In the first German census: 70,629 or $50.15 \%$; in the second one: 74,466 or 53.65\%. After: F. $79-819$ fol. 1-4 RV [The number of Lithuanians in Vilnius...]

28 Statistical data for the central authorities, see Werbelis: Russisch - Litauen. Statist. Etnogr. Betrachtungen, Stuttgarth, 1916, p. 88, Fig. XIX.

29 Vilniaus Aidas, 1916, p. 66-74.

30 According to another Lithuanian calendar Lietuviu kalendorius 1917, Wilno, 1916, published by Ant. Rucewicz, there were 3,671 Lithuanians, which also accounted for 2.68\%. F. $79-819$ fol. 1-4 RV [The number of Lithuanians in Vilnius...]

31 The census was conducted based on oral statements in the presence of an office clerk and four delegates: a Pole, a Lithuanian, a Belarusian, and a Jew. F. $79-819$ fol. 1-4 RV [The number of Lithuanians in Vilnius...] F. 79 -819 fol. 1-4 RV [The number of Lithuanians in Vilnius...]

32 Vincas Mickevičius-Kapsukas [Винцас Мицкявичюс-Капсукас] (1880-1935), Lithuanian communist politician and journalist, Comintern activist, one of the founders of the Communist Party of Lithuania, Chairman of the Central Committee of the Communist Party of Lithuania and Byelorussia of the Lithuanian-Byelorussian Soviet Socialist Republic. In December 1917 he joined the People's Commissariat for Nationalities, where he assumed leadership of the Lithuanian Department. He was actively involved in the preparation of groundwork for the establishment of 
The Vilnian Poles, who had been sorely affected by the politics of the OberOst administration, ${ }^{33}$ considered it obvious after 11 November 1918 that "their" city was Polish. But the Polish Congress in Vilnius took place only 6 weeks after 11 November, on Christmas Day of 1918, in the shadow of the Bolshevik threat. Incidentally, this was the only congress that the German authorities consistently and deliberately prevented from convening during the entire period of the OberOst occupation. During the sessions, whose course is known from press reports, the assembled Polish activists did not appoint either the Polish Provisional Government of Lithuania nor the Polish Government Commission in Lithuania. ${ }^{34}$ On the other hand, they probably did select the delegates from Lithuania to the Legislative Sejm in Warsaw..$^{35}$ This way they expressed a clear position on the future of the Lithuanian lands of the former Commonwealth.

Soviet Lithuania. From 27 February to 4 July 1919, he acted as head of the Council of People's Commissars of the Lithuanian-Byelorussian Soviet Socialist Republic (Lit-Bel).

33 See: J. Gierowska-Kałłaur, preface to: A. Szklennik, Wspomnienia o wydarzeniach $w$ Wilnie i w kraju. Dziennik, part 1, comp. by J. Gierowska-Kałłaur, in: Metamorfozy społeczne, vol. 18, Warszawa, 2018, pp. 7-37.

34 P. Łossowski (Konflikt polsko-litewski 1918-1920, Warszawa, 1996, p. 29) reports the establishment of the Provisional Polish National Council in Lithuania based on a work by J. Jurkiewicz (Rozwój polskiej myśli politycznej na Litwie i Białorusi w latach 1905-1922, Poznań, 1983, pp. 173-174). The examination of this title (and my twenty-year-long query in Vilnius archives) allows me to state that the Provisional Polish National Council in Lithuania did not in fact start operating before 4 January 1919. On that day, the Polish Committee was dissolved and the Council took over its competences. A. Deruga (Polityka wschodnia Polski wobec ziem Litwy, Białorusi i Ukrainy [1918-1919], Warszawa, 1969, p. 67) in turn mentions "a lack of activity on the part of the Polish side” in December 1918. M. Gałędek (Ustrój administracji ogólnej na Wileńszczyźnie w okresie międzywojennym, Gdańsk, 2012, p. 49) claims that the Polish Government appointed the Government Commission, but the nominees: W. Abramowicz, K. Niedziałkowski, A. Zwierzyński, S. Kognowicki, K. Świątecki, and J. Piłsudski did not accept the nomination. In addition, Stefan Mickiewicz illegitimately proclaimed himself representative of the Polish Government. It should be mentioned that the only known list of members of the Provisional Polish National Council in Lithuania comes from the beginnings of the Civil Administration of the Eastern Territories [Zarzad cywilny ziem wschodnich, ZCZW] (IV 1919-IX 1920). It is held at the LCVA in Vilnius and contains the names of 50 members (with their first names and addresses). Twenty members (and three candidates for members) from the Vilnius region; six (and five candidates) from the Kaunas region; two members from the Suwałki and Grodno regions; fifteen from the city of Vilnius and five from the Vilnius county outside the demarcation line.

35 The ordinance to the Legislative Sejm in Warsaw was announced on 28 November and did not cover the Lithuanian and Belarusian lands of the former Grand Duchy of Lithuania, and the fact that three counties, considered by Lithuanian and Belarusian politicians to be exclusively "their own," were included in it became the source of a number of anti-Polish speeches by politicians from the Belarusian People's Republic [Bielaruskaja Narodnaja Respublika, BNR] in the international forum. The Legislative Sejm did not co-opt the Polish delegates from Lithuania to its assembly, which they had sought in February 1919. 


\section{The situation in Vilnius in December 1918}

The documents discussed here clearly show that the actual administrative power in Vilnius from November to December 1918, despite the declarations of Lithuanian politicians from opposite sides of the Lithuanian pantheon (Augustinas Voldemaras ${ }^{36}$ and Vincas Mickevičius-Kapsukas), was still held by the German authorities. The Polish Military Information Report of 1 January $1919^{37}$ reads:

The soldier's councils formed in Wilno do not play a major role. They rather serve as a supervisory institution. The attitude of German soldiers towards the officers has improved. The local destructive elements, as well as the arriving Bolsheviks and Jews [!] have instigated a frantic pogrom operation against the propertied spheres, which consist predominantly of Poles [!]. Bands have formed out of local people, mostly Orthodox and Old Believers, led by individuals that arrived from Russia. They have plenty of weapons (almost every village has a machine gun). In addition to the wave of Bolshevism from the East, Wilno faces a threat directly from within. The Jews have an organised militia of 5,000 people armed with machine guns and rifles. Their aim is to seize power at the appropriate moment in order to prevent the merger of Wilno with Poland. For the last 2-3 weeks, the Jews [!] have been transporting huge loads of weapons of all kinds from Mołodeczno to Wilno. The staff of the self-defence forces has meagre funds at its disposal, raised from contributions. The self-defence forces have bought 500 rifles with 100 cartridges each and 2 machine guns. ${ }^{38}$

36 Augustinas Voldemaras (1883-1942), Lithuanian historian and national political activist, member of the Taryba (Lithuanian State Council), sworn in on 11 November 1918 as the first Prime Minister of the Lithuanian Government; he held this office until December. He then served as Minister of Foreign Affairs until 1920.

37 RGVA 471K-2-11 fol. 17, Raport Informacyjny wojskowy z dnia 1 stycznia 1919 roku. Sztab Generalny WP 1./VI./1. Oddział VI Wschód. Litwa. The report contains other information: "Soły. On 26/12/[1918], on the Petersburg line the Bolsheviks seize Bezdany. Minsk. 8,000 Bolshevik soldiers, art[illery] and cavalry are marching from Mińsk towards Wilno. They appear as a fine army. In Mińsk, the draft of all men 20-40 years of age has been announced. Self-defence in complete disintegration. Only rapid military assistance would save the situation. The Germans were ordered by the Coalition to reclaim Święciany from the Bolsheviks. Messara, Dzisna county. A band of about 2,000 thugs, led by former Russian officers, is prowling the area, they have two field cannons. In the Dzisna and Wilno counties, the bands are burning villages. Świenciany [!]. The Bolsheviks have announced the draft of the three youngest year groups. Witebsk. There are 400 people here with eight machine guns, part of the West Bolshevik Division (headquartered in Mińsk). The $3^{\text {rd }}$ Riflemen's Division is being formed. Col. Gegstrem appointed commander of the $3^{\text {rd }}$ Brigade. One platoon of cavalry, 50 men, 20 artillery horses [!]. One unit of field artillery is being formed (around 20 officers, a dozen horses, no cannons so far). Markowszczyzna. A part of the west division is stationed here, an infantry regiment is being formed. 50\% of Poles [!] / machine gun unit/around 50 people/dismounted cavalry/100 people/. Włodawa. Despite the agreement the Germans have not withdrawn from Domaszów so far."

38 RGVA Fond 471K-2-11 fol. 17, Raport Informacyjny wojskowy z dnia 1 stycznia 1919 roku. Sztab Generalny WP 1./VI./1. Oddział VI Wschód. Litwa. 
Following the Polish Congress, which took place in Vilnius on 26-27 December, the commander of Vilnius Self-Defence, General Wejtko, dissolved said unit on 29 December and ordered all its members to immediately join the Polish Army in Vilnius. The hitherto voluntary formations thus became part of the Polish Armed Forces. The Military District of Lithuania and Belarus was established. ${ }^{39}$ Perhaps this information did not reach the author of the Information Report of 1 January 1919, since he would consistently describe the Polish units in Vilnius as "Self-Defence." He informed that about 600 soldiers and 300 officers had been registered. According to the information provided to the General Staff, they were "of a good spirit" and there were many yet unregistered men in the countryside who were successively being drafted. What is also important is that, in addition to legionnaires, the volunteers comprised Poznanians from the German army. The author of the report wrote of them as follows: "Everyone wants to join our army. They are extremely helpful in self-defence, providing various materials and weapons that they take away from the germans [sic]." ${ }^{40}$

At the exact same moment, Gopner reported that before the entry of the Red Army into Vilnius, the Bolsheviks had been negotiating with the Germans regarding assistance from the Sovdep [Sovet deputatov = Council of Deputies] in disarming the Whites, in exchange for the Germans leaving material assets untouched. However, "the talks were interrupted by Comrade Petrov, who realised that he was being followed and disappeared." 41

Meanwhile, in Vilnius, the Germans and Bolsheviks were apparently on excellent terms. According to Polish information, 8,500 prisoners of war from the German army had passed through Vilnius within 3 days, whom the Bolsheviks would recruit to the Red Guard without hindrance, tempting them with huge advances on account of their wages. The city was flooded with appeals to disarm the bourgeoisie and give their weapons to the proletariat. According to the same source, the Germans would plunder the homes of Vilnian residents at night, which triggered panic among the city intelligentsia and the landowners who had found refuge in Vilnius.

In view of the Bolsheviks approaching Vilnius and the impossibility of obtaining military support for the defence of the city from outside forces, ${ }^{42}$ it seemed logical that the units present in the city should work together to defend themselves.

39 W. Wejtko, Samoobrona Litwy i Białorusi. Szkic historyczny, Wilno, 1930, p. 9, Annex 6, pp. 69-80.

40 RGVA Fond 471K - 2 - 11 fol. 17, Raport Informacyjny wojskowy z dnia 1 stycznia 1919 roku. Sztab Generalny WP 1./VI./1. Oddział VI Wschód. Litwa.

${ }^{41}$ Gopner, 15 January 1919.

42 The first troops of the Polish Army were only being formed in Warsaw and they were immediately dispatched in support of Lvov, which had been fighting since 1 November 1918. Vilnius was only granted financial support by the Commander-in-Chief (a suitcase of money was brought by Cpt. Zygmunt Klingier). 
However, the precondition for Lithuanian cooperation with the troops commanded by Gen. Wejtko was the recognition by the Polish state of the Lithuanian state, independent since 16 February 1918, with Vilnius as its capital.

\section{Polish-Lithuanian negotiations on the defence of Vilnius}

This issue has been discussed in detail by Piotr Łossowski, expert on PolishLithuanian relations. The Lithuanians had announced the existence of their independent state almost 11 months earlier. Vilnius was consistently declared the capital of this state. Therefore, the Lithuanian side decided that it was not appropriate, in terms of the Lithuanian raison d'état, to join the Polish-led defence of this Polish-Jewish city as, in their opinion, this defence was only "supposed to prove the Polishness of the city," 43 which, of course, was at odds with the strict national interest of the Lithuanian state. At the request of the new ${ }^{44}$ Lithuanian Prime Minister Mykolas Sleževičius, ${ }^{45}$ the Lithuanian Minister of National Defence informed the Polish legionnaires (as the Polish soldiers were commonly referred to) that they may participate in the defence of the country only as part of the army under the authority of the Lithuanian government. However, there were no significant Lithuanian troops in Vilnius at that time, contrary to Polish ones, so the Polish side refused to accept this condition, deemed unfounded.

One of the last unsuccessful attempts to reach an agreement between the Poles and the Lithuanians in Vilnius was mediated by a well-known Lithuanian lawyer, Jonas Vileišis, the erstwhile Lithuanian Minister of Interior. ${ }^{46}$ The basic precondition for the agreement proposed by the Poles was the establishment, without

${ }^{43}$ Expression used by Antanas Rukša in his work Kovos del Lietuvos nepriklausomybes, vol. II: Lietuviu-lenku santykiai ir kovu pradzia, Cleveland, 1981, p. 153; after: P. Łossowski, op. cit., p. 30.

${ }^{44}$ The hitherto Prime Minister Voldemaras left for Berlin in order to obtain a significant financial loan from the Germans.

45 Mykolas Sleževičius (1882-1939): Lithuanian lawyer, journalist, agrarian activist; in the years 1917-18 he presided over the Supreme Lithuanian Council in Russia. Imprisoned by the Bolsheviks, he returned to Lithuania after his release. From December 1918 to March 1919 and from April to October 1919 he served as Prime Minister of Lithuania. His government was considered strongly anti-Polish.

${ }^{46}$ Jonas Vileišis (1872-1942), appearing in Polish literature as Vilešys: Lithuanian journalist, politician and lawyer. During the first phase of the Ober-Ost occupation, he co-organised Lithuanian education and social assistance; he was arrested by the German authorities. From the autumn of 1917 to 1920 he was involved in the works of the Taryba. He was one of its four members who objected to the so-called Independence Act of 11 December 1917. Author of the new declaration of independence adopted on 16 February 1918. Member of the Social Democratic Party of Lithuania (1917-1922). On 18 December 1918 he was appointed Minister of the Interior in the Second Lithuanian Government (until March 1919). In the fourth cabinet, he served as Minister of Finance (June-October 1919), resigned on account of assuming a diplomatic post in the United States. 
prejudice to the political system, of a state union between Lithuania and Poland. The Lithuanians, however, insisted that the Polish state and Polish community in Lithuania recognise the independent national state of Lithuania with Vilnius as its capital.

On 1 January 1919 Witold Abramowicz read out a statement by the Polish side, which was seeking consensus:

In recognising the independence of the Lithuanian state in ethnographically Lithuanian territories, we consider the demarcation of borders between Poland and Lithuania and the settlement of contentious issues depending on the legal nature of the relationship binding the two countries. ${ }^{47}$

The efforts of the negotiators came to naught. In spite of the dire military situation, the supreme Lithuanian authorities did not consider the defence of Vilnius a priority. Lithuania's desire to have Vilnius exclusively for themselves prevailed over the impulse to defend the city from the Bolsheviks. The Taryba and the Lithuanian government left Vilnius and travelled to Kaunas aboard the last German ${ }^{48}$ evacuation train. They were followed by the politicians of the BNR. As a result, only Polish troops took up the defence of Vilnius against the Bolsheviks.

\section{The military situation in the lands of historical Lithuania during wartime in January 1919}

In his reports of 6 and 15 January 1919, Gopner describes not only the moods prevailing in December 1918 in Vilnius, but also those in the Vilkomir and Kovno Governorates.

And so, in the Vilkomir Governorate, authority was "in the hands of a bourgeois committee," which assembled a 21-strong militia composed of former city guards. The Red Army intelligence agents were active in Prudy and Kurily in the Volkovysk County, and the majority of the population of this area referred to them "adequately." The situation was unusual in Kibarty, ${ }^{49}$ where the Germans were arresting active participants of a strike that had taken place there. At the same time, according to Gopner's data, the Germans were conducting an intensive evacuation operation, as 10 trains a day were crossing the border in Kibarty

47 P. Łossowski, op. cit., p. 30.

48 After the capitulation of Germany (11 November 1918), the German army was allowed to remain in the eastern territories with the consent of the Entente. This issue has been discussed extensively by Piotr Łossowski in his works.

49 Kibartai: town in Lithuania, in the present-day Marijampole County, close to Vilkaviškis, seat of the Kibarty Municipality; located near the border with the Kaliningrad Oblast. Until 1918 Kibarty was located in the Kingdom of Poland, in the Suwałki Governorate, Wyłkowyszki County, Kibarty Municipality. 
and Wierzbołów. ${ }^{50}$ (According to Gopner's report, the Germans would take all machinery from the occupied area with them.) But they still sent 200 volunteer soldiers to carry out a series of arrests, including that of Balajtis, the organiser of the strike in Kibarty. Since the soldiers' council in Kibarty refrained from attempts to have the arrested released, a crowd of 600 people spontaneously marched on the Kreis-amt seat, but the mass was dispersed by gunfire and further arrests took place.

The situation was quite different in Lida, where no one wanted to seize power. The withdrawal of the Germans from Lida caused sincere upset to the local soldier's council and there was still no one willing to take power in the city.

In the Kovno Governorate, in the city of Ponevezh (Panevežys), from which the Red Army was still far away, the situation was completely different than that in Lida. The city councils and committees set up by the Germans did establish a militia of 60 former guards. However, on 19 December [1918], riots took place in the workers' community. A "red" crowd assembled in the square, with the 60 militiamen being largely helpless. After the rally, the crowd dispersed around the city, but 25 participants gathered for their first meeting. According to Gopner, "there were 21 members, including 14 communists." The council was immediately constituted and, at its very first meeting, it proclaimed itself the "All-Russian Workers' and Peasants' Council [rendered as "VRRK" in the original document] of the Government of Lithuania and the Soldiers' Councils [ $\left.{ }^{51}\right]$ of the $10^{\text {th }}$ Army in Vilnius." One of the founding members of this Council was undoubtedly David Y. Gopner, who wrote: "We received information that our Vilnius Council of Representatives is under threat from Polish legionaries and Whiteguardists." The assembly gathered in Ponevezh therefore decided that Vilnius should be seized as soon as possible to ensure "that the Workers' Council in Vilnius could proceed with its works on instituting Soviet power and order in the city." Gopner was also concerned about the not entirely bright perspectives of said Workers' Council establishing relations with the soldiers of the German $10^{\text {th }}$ Army stationed in Vilnius. The author of the report was afraid of bloodshed in the form of clashes with the soldiers of the $10^{\text {th }}$ Army, whom, according to declarations, the Workers' and Peasants" Government "saw as their brothers." This requires a commentary. It appears that Gopner's disquiet resulted from the simple reason that a considerable percentage of these German soldiers (especially in the last and first year of the Ober-Ost occupation) were Polish-speaking residents of Poznań, Silesia or Pomerania. ${ }^{53}$ A large part of them deserted from the German army in December

${ }^{50}$ Virbalis: town in Lithuania, located in the present-day Marijampole County, $12 \mathrm{~km}$ from Vilkaviškis.

51 Text almost illegible.

52 Gopner, 15 January 1919.

53 A. Szklennik mentions the Polish soldiers in German service in Vilnius in his diary Wspomnienia o wydarzeniach $w$ Wilnie $i$ w kraju [Memories of the events in Vilnius and in the country]. For example: entries of 11 June 1916, 5 December 1916, etc. The German authorities even issued 
1918 and stayed in Vilnius, probably to defend the city together with their compatriots against the Bolshevik offensive.

The first report of the Sixth Department of the Polish General Staff tells us that on 26 December (1918) the approaching Bolsheviks seized Bezdany, and announced the draft of the three youngest age groups in Swięciany. In the Dzisna County, in turn, a gang of 2,000 thugs was active, commanded by former Russian officers and equipped with two field cannons. In Vitebsk, a part of the western Bolshevik division and the $3^{\text {rd }}$ Riflemen's Division were being formed, and Lieutenant Colonel Yevgeny Gegstrem was appointed commander of the $3^{\text {rd }}$ Brigade. ${ }^{54}$ The division was headquartered in Minsk. In Markowszczyzna, ${ }^{55}$ an infantry regiment (with a 50-strong machine gun unit) and a dismounted cavalry unit of 100 people, consisting of $50 \%$ Poles, were being formed. Just as the Lithuanians did not take part in the defence of Vilnius, neither did any Belarusian troops stay to defend Minsk, with the 1,929 soldiers and 200 horses from the Self-Defence of the Minsk Land withdrawing from the city to later become an important addition to the Lithuanian-Belarusian Division. ${ }^{56}$ In Minsk, immediately after the capture of the city, the Bolsheviks announced the draft of all men between 20-40 years of age. According to Polish intelligence sources, as many as 8,000 Bolshevik soldiers were marching on Vilnius.

With the six military information reports of the Supreme Command of the Polish Armed Forces of 21 January and 3, 10, 19, 24 and 25 February 1919 held in the archives of Moscow at our disposal, ${ }^{57}$ we may attempt to recreate the atmosphere of the first months of 1919 in the lands of the former Duchy of Lithuania. In January 1919, Grodno was threatened by significant Bolshevik forces. The Polish military sources estimated their number in the Vilnius region alone

a printed order banning speaking to the soldiers. Considering the fact that the knowledge of the German language was rare in Vilnius, and that German soldiers hardly knew Russian or Yiddish, the scale of the problem must have been significant.

54 Гегстрем Евгений-Александр Элисович (1871-1926 начальник штаба 3-й стр. дивизии. Командир бригады 3-й дивизии в Витебске, See: http://pskovgrad.ru/war/pervaya-mirovaya-vojna/25285-gegstrem-evgeniy-aleksandr-elisovich.html

55 Markowszczyzna: natural landmark connected with the Wolna estate, in the Baranowicze County of the later Nowogródek Voivodeship.

56 RGWA 471K-2-11 fol. 17-17v, Raport Informacyjny wojskowy z dnia 1 stycznia 1919 roku. Sztab Generalny WP 1./VI./1. Oddział VI Wschód. Litwa.

57 RGVA 3089582 fol. 15-19, Sztab Generalny WP Tajne . nr 592/VI/7 . Oddz. VI Wojskowy Komunikat Informacyjny z dnia 21 I 1919 Grodno; RGVA 3089582 fol. 37-39, Sztab Generalny WP Poufne Nr 933/VI/10 Oddz. VI Wojskowy Komunikat Informacyjny z dnia 3 II 1919 Wilno; RGVA 3089582 fol. 44-48, Sztab Generalny WP nr 1114/VI/12 Oddz. VI Raport Informacyjny Wojskowy z dnia 10 II 1919. Wschód. [Akapit] Wojska niemieckie na Wschodzie; RGWA 3089-582 fol. 80-85, Sztab Generalny W.P. Tajne 1396/VI/16 O VI Raport Informacyjny Wojskowy z dnia 19 II 1919; RGWA 3089582 fol. 105-113, NDWP Nr Sztab Generalny 1689/VI O VI Raport Informacyjny Wojskowy z dnia 24 II 1919; RGWA 3089582 fol. 114-117, Sztab Generalny W.P. 1699/VI/18 O. VI Raport Informacyjny Wojskowy z dnia 25 II 1919. 
at 12,000 people. ${ }^{58}$ The Poznanians of the German army who remained in the city captured by the Bolsheviks (there were quite a few of them there) were considered marauders and risked being executed. The already tense situation in Vilnius was exacerbated by the local Jews, who would turn these "German deserters" and "Polish soldiers" in to the Bolsheviks. News from reliable sources about numerous executions reached Grodno. ${ }^{59}$ (For the record. My research so far has shown ${ }^{60}$ that the subject of Polish-Jewish relations in Vilnius during the First World War and the Polish-Soviet War still requires many arduous archival queries. It is definitely too early for summaries and comments. That is why, for the time being, I have adopted the principle of providing bare details with a precise indication of their source.)

The German armed forces in Grodno, hostile towards Poles, amounted to around 1,000 people in the first decade of February 1919. These were the remnants of the $10^{\text {th }}$ Army and soldiers from volunteer units. German volunteers preferred to fight the Poles rather than the Bolsheviks. ${ }^{61}$ As they were to retreat from Grodno, the German command rejected the possibility of the Polish Army taking their place. ${ }^{62}$ In this situation the Grodnian Poles demanded weapons for their units, but the Germans refused due to the categorical objection by Anton Luckievich. In addition, the already existing Polish unit of Gen. Mikołaj Sulewski ${ }^{63}$ was

58 RGWA 308 -9 -582 fol. 80-85, Sztab Generalny W.P. Tajne 1396/VI/16 O VI Raport Informacyjny Wojskowy z dnia 19 II 1919. This is the kind of information that was incoming at that time from Vilnius.

59 RGVA 3089582 fol. 37-39, Sztab Generalny WP Poufne Nr 933/VI/10 Oddz. VI Wojskowy Komunikat Informacyjny z dnia 3 II 1919 Wilno.

${ }^{60}$ J. Gierowska-Kałłaur, “Żydzi i Polacy na Wileńszczyźnie w latach 1919-1920,” in: Świat NIEpożegnany. Żydzi na dawnych ziemiach wschodnich Rzeczypospolitej w XVIII-XX w., ed. K. Jasiewicz, Warszawa-Londyn, 2004, pp. 354-365; id., “'Depozyty’ Walerego Sławka przechowywane w Moskwie. ('Biuro Detaszowane Oddziału II Naczelnego Dowództwa 1919')," Studia z Dziejów Rosji i Europy Środkowo-Wschodniej, 47, 2012, pp. 208-272; id.: "Wpływ zmiany okupanta na miejską wielonarodowościową społeczność. Przypadek Wilna w latach I wojny światowej," in: Gorad i âgo žyhary: portrèt na fone èpohì. X-XX stst., ed. A. F. Smalenčuk, Mìnsk, 2016, pp. 145-161; id., "Stanisław Bułak-Bałachowicz. Postać, która mogła połączyć narody byłego Wielkiego Księstwa Litewskiego, a jednak ich nie połączyła," Acta Baltico-Slavica (Polska - Litwa Białoruś. historia, która dzieli $i$ łączy), 2017, no. 41, pp. 77-155, including on an open letter from Stanisław Bułak-Bałachowicz to Boris Viktorovich Savinkov dated 16 August 1921, which touches on, inter alia, of the attitude of Boris Savinkov and his troops towards Jews (pp. 113-137).

${ }^{61}$ RGVA 3089582 fol. 44-48, Sztab Generalny WP nr 1114/VI/12 Oddz. VI Raport Informacyjny Wojskowy z dnia 10 II 1919. Wschód . [Akapit] Wojska niemieckie na Wschodzie.

62 RGVA 3089582 fol. 105-113, NDWP Nr Sztab Generalny 1689/VI O VI Raport Informacyjny Wojskowy z dnia 24 II 1919: "In Lithuania and the Suwałki Region, the Germans are leaving the occupied territories and withdrawing behind the East Prussian border. They do not consent to the immediate entry of the Polish Army into Grodno."

${ }^{63}$ Mikołaj Sulewski (1859-1943): Brigadier General of the Polish Army. He was born in the Grodno region. On 12 December 1918 he was admitted to the Polish Army by J. Piłsudski and appointed commander of the Self-Defence of the Grodno Land. Upon the return to Grodno, Polish military 
disarmed. ${ }^{64}$ The Germans actively counteracted the recruitment campaign conducted by the Polish Military Organisation (notably by arresting Lt. Łęczycki), ${ }^{65}$ and the existing Grodno Self-Defence units were disarmed and moved to Białystok. General Mikołaj Sulewski was also arrested with his staff and transported to Łapy. ${ }^{66}$

\section{The position of Belarusian politicians in the new strategic and political situation}

Anton Luckievich left Vilnius with a passport issued by the Lithuanian Ministry of Foreign Affairs. This was due to the fact that neither Germany nor either of the Lithuanian governments had recognised the BNR. The Belarusians had the status of a Lithuanian minority since November 1918, so it was logical that they did not oppose the Lithuanian authorities. The situation of the Belarusian patriots was further complicated by the fact that the Bolsheviks tried to infiltrate Belarusian structures by secretly swaying the more active individuals to their side. For example, a close associate of Anton Luckievich, acting Minister of Interior Kuzma Tsiareshchanka, established contact with the Vilnian Municipal Bolshevik Council of Workers' Deputies in December 1918, and acted according to the instructions received. Symon Jakaviuk, Anton Luckievich's close collaborator, became a Bolshevik agent in September 1918. ${ }^{67}$

The rallying of local Poles intensified the concern of politicians of the Belarusian People's Republic [Bielaruskaja Narodnaja Respublika, BNR]. On 3 January 1919, Prime Minister Anton Luckievich submitted a protest note to Leon Wasilewski, the Polish Foreign Minister, regarding the announcement of the general mobilisation

commands established in fifteen communes of the Grodno and Sokółka communes subordinated themselves to the Self-Defence. Under an agreement with the Germans, the Grodno Rifle Regiment was being formed under the command of Major Jan Jackiewicz.

${ }^{64}$ RGVA 3089582 fol. 15-19, Sztab Generalny WP Tajne nr 592/VI/7. Oddz. VI Wojskowy Komunikat Informacyjny z dnia 21 I 1919 Grodno.

65 "In recent weeks, Mr Łęczycki was arrested in the Grodno region and tried for belonging to the Polish Military Organisation [Polska Organizacja Wojskowa, POW] (which was treated as anti-German propaganda). In the prison with Łęczycki there was a certain number of legionnaires enduring misery and left with no medical care. The Germans do not issue passes to young people, thus preventing the transfer of volunteers. The border line is heavily manned. Lithuanian troops of 5,000 men; the officer cadre consisting mostly of Dowbor's $1^{\text {st }}$ Corps, saying goodbye to their colleagues leaving for the Polish Army 'Come back quickly, we will prepare the ground here.' Belarusian troops in Grodno of 500-600 people (including 200 cavalry). All have rifles, also 10 machine guns. The regiment is commanded by a fierce Belarusian, Jezovitov. The Belarusian regiment is to be incorporated into the Lithuanian army."

${ }^{66}$ RGVA 3089582 fol. 114-117, Sztab Generalny W.P. 1699/VI/18 O. VI Raport Informacyjny Wojskowy z dnia 25 II 1919 uzupełniony informacjami z biogramu gen. Mikołaja Sulewskiego w PSB autorstwa Jerzego Adama Radomskiego.

67 D. Michaluk, Białoruska Republika Ludowa 1918-1920, Toruń, 2010, pp. 377. 
of the Polish Army by the Commander of the Military District of Lithuania and Belarus of the Polish Army ${ }^{68}$ No official Belarusian protest (BNR) is known to have been filed against the successive occupation of Belarusian lands by the Soviets.

\section{When did the Polish-Soviet War begin?}

There is a discrepancy between the Soviet/Russian and Polish historical narrative, and even between Polish historians, as to when the Polish-Soviet War actually began. At least three dates are quoted: (1) early January 1919, when the Soviets seized Vilnius, (2) mid-February 1919, when the front-line operations began, and finally (3) April 1919, when Poles conquered Vilnius from the Bolsheviks and put an end to the existence of Lit-Bel. It is reasonable to assume that in Polish historiography the majority of researchers agreed that the war had started in mid-February 1919. The documents found and discussed here clearly resolve the issue. Waldemar Rezmer is right. The war was sparked by the Soviet attack of 4 January 1919 on the Polish legionnaires of the Lithuanian-Belarusian Military District of the Polish Army ${ }^{69}$ On 3 January 1919 Anton Luckievich protested the announcement of the general mobilisation by the commander of the Military District of Lithuania and Belarus subordinate to the Supreme Command of the Polish Army. ${ }^{70}$ The clashes between the Polish and Bolshevik forces, which began on 4 January 1919, were the first instance of units formally belonging to the Red Army and the Polish Army fighting against each other.

David Yulevich Gopner decided to personally take part in the attack on Vilnius-as he explained in his report of 6 January 1919-to "increase the morale of the attackers." This was necessary, given the alarming phone call from Podbrodzie by Commissar Norvidas in the evening of 5 January, informing "the energetic, unpredictable and fierce but easily and unreasonably discouraged comrade Kapsukas-Mickevičius" of a serious conflict caused among the War Council by the "inexperienced and undisciplined commissar of the Samogitian regiment who had delayed the offensive." ${ }^{" 11}$ As a consequence of these circumstances,

68 Archivy BNR (ABNR), vol. 1, part 1, no. 1161 [Note of 3 I 1919].

69 W. Rezmer, “Начало польско-советской войны 1919-1920 гг.: исследовательский вопрос," in: Чичеринские чтения. Россия и мир после первой мировой войны (К 90-летию окончания войны и подписания послевоенных соглашений). Материалы международной научной конференции 11-12 ноября 2008 г., Тамбов, 2009, pp. 266-281; id., “4 stycznia 1919 roku początek wojny Polski z Rosją Sowiecką,” Przegląd Historyczno-Wojskowy, 2009, no. 1, pp. 55-68; id., "Когда и почему началас война между Польшей и Советской Россий? Историография вопроса," in: Россия и Польша: долг памяти и право забвения (Москва, 22-24 октявря 2009 г.). Тезисы докладов, Москва, 2009, р. 76.

70 W. Wejtko, Samoobrona Litwy i Białorusi. Szkic historyczny, Wilno, 1930, p. 9., Annex 6, pp. 69-80; ABNR vol. 1, part 1, no. 1161.

${ }^{71}$ Gopner, 15 January 1919. 
on 4 January 1919, the $5^{\text {th }}$ Vilnius Regiment, which had already seized Antokol [sic], was forced to retreat from Vilnius to Niemenczyn, 16 versts farther. "Couriers from Vilnius" were expected in Podbrodzie to confirm the news that the surrounded Vilnius Workers' Council (a.k.a. the Vilnius SovDep), had surrendered to the "legionnaires" (soldiers of the Military District of Lithuania and Belarus of the Polish Army) after 20 hours of resistance. The news obtained from the couriers was quickly verified by Gopner. The information that some of the SovDep members had committed suicide in order to avoid surrender was true, but the claim that some of them were members of the government was false. ${ }^{72}$

On the night of 5 January, Gopner travelled to Vilnius accompanied only by Stanisław Pestkowski, ${ }^{73}$ though the members of the (communist) Lithuanian Government insisted on the participation of Mickevičius-Kapsukas in the journey. ${ }^{74}$ In Gopner's opinion, these people paid excessive attention to leaving "red Polish-Lithuanian troops" [sic] in the city. It is possible that the insistence of the "Lithuanian authorities and Pestkowski" to keep the units considered to be the "fiercest Polish-Lithuanian units" for as long as possible in the city was a sign of an attempt to save the soldiers of these Polish-Lithuanian units with a view to a future, separatist action.

Initially, Gopner was misled by the tip-offs. His informants were residents of Vilnius. According to their accounts, the city was under Polish control, while Gopner found that the "legionnaires" were only holding the Wielka Pohulanka and Piaski areas. Gopner reported:

72 The most valuable point of resistance was the building at ul. Wronia, which was the seat of the Vilnius City Council of Workers' Deputies, established on 15 December 1918 and consisting not only of local communists but also of a certain number of outsiders. It was chaired by Kazimierz Cichowski, secretary of the Petrograd group of Social Democrats of the Kingdom of Poland and Lithuania (SDKPiL), while the duties of secretary of the presidium belonged to Jan Kulikowski, a Pole from the Troki County, a member of the SDKPiL and the Communist Workers' Party of Poland. For more on the events at ul. Wronia, see: L. Wyszczelski, Wojna polsko-rosyjska 1919-1920, $1^{\text {st }}$ ed., vol. 1, Warszawa, 2010, pp. 50-53.

73 Stanisław Pestkowski, a.k.a. Andrzej Borowski (Станислав Станиславович Пестковский) (b. 3 December 1882 in Kiełczygłów, d. 15 November 1937 in Moscow): Polish and Russian worker movement activist, communist. Between 1917 and 1919, he was deputy commissar at the Commissariat for Nationalities. Then, at the request of the Council of People's Commissars of the RSFSR he was delegated to the west of Russia to participate in the establishment of the Byelorussian People's Republic.

${ }^{74}$ Commissar Norvidas reported on the conflict in the War Council literally: "it was due to the reprehensible delay of the offensive by the conceited and inexperienced commissar of the Samogitian regiment and the allowing of a violation of the plan of offensive." (A detachment of the Pskov Division had moved forward and occupied Vilnius, while according to the adopted plan the $5^{\text {th }}$ Vilnius Regiment was to launch the operations). As a matter of fact, the commissar of the Samogitian regiment was not very well regarded by Gopner; he viewed him as a demagogue who deliberately provoked animosities and conflicts among the troops. 
The opponent showed no resistance; contrary to information from the Jews, they had no artillery, nor a significant number of bayonets. Nor had they the will to resist. Nearly no victims on both sides [...] if our troops had entered Vilnius one day later, the pogrom of Jews and the slaughter of workers would have already taken place. The pogrom was prepared to the smallest details. This is why not only the proletariat, but also the small Jewish bourgeoisie welcomed the red troops with admiration. ${ }^{75}$

Gopner felt obliged to name two activists as co-authors of the Soviet success in Vilnius: the military commissar of the Western Front, comrade Morozov, as well as a member of the Lithuanian Government, representative of the War Revolutionary Committee and, at the same time, the most committed and energetic member of the government, comrade Weinstein-Baranovski.

\section{Evaluation of the situation in Vilnius immediately after the seizure of the city by the Bolsheviks}

According to Gopner's account, during the funeral of the suicide victims from the Vilnius SovDep, ${ }^{76}$ the residents of the city allegedly displayed a rarely encountered favourable attitude towards Soviet troops, which he interpreted as "an expression of similar political views." This in turn led him to the conclusion that "the future efforts of the Soviet authorities would undoubtedly be carried out in very suitable conditions and would not be sabotaged." "77 Gopner believed that the entry of the red troops into Vilnius was accompanied by a "moment of elation and omnipresent hope."

The question remaining: to what extent was this image realistic, or created in order to obtain approval from the superiors? The fact is that, in his account, Gopner remarked that he had no information on the Vilnian Poles. He did anticipate, nonetheless, the success of both the recruitment of volunteers to the Red Army and the mobilisation. The necessary condition for success was, according to him, to send in military instructors within the shortest time possible and to organise supplies. He reported that

despite the poor condition of the labour unions [...] the order in the city is exemplary, there are rallies, marches and meetings everywhere and the townspeople are fascinated by the Red Army soldiers. [...] my observations made on the grounds of my knowledge of Vilnius convince me that there is no other place where conditions for the success of the Soviet rule would be so favourable. ${ }^{78}$

${ }^{75}$ Gopner, report of 15 January 1919.

76 According to Dorota Michaluk's findings, among the suicides were the commander of the people's militia L. Czapliński and the Vilnian shoemaker Bonifacy Wierzbicki. D. Michaluk, Białoruska Republika Ludowa 1918-1920. U podstaw białoruskiej państwowości, Toruń, 2010, pp. 364-366.

77 Gopner, report of 15 January 1919.

78 Ibid. 
Such an assessment of the exemplary order and of the extraordinary pace of preparatory works in the city and its offices allowed the new authorities to lift the siege as early as on 11 January 1919.

The appeal of the Provisional Government did not yield the expected results, and the failure was largely due to the fact that this was not the first such initiative made in Vilnius. The announcement made by the Sovdep was preceded by that of the Vilnian Socialists-Revolutionaries. However, the latter proved unsuccessful, since the Sovdep did not agree to the creation of a government without its participation and refused to recognise the Military Revolutionary Committee. Both groups mutually hindered each other's political manoeuvres. According to Gopner, the Vilnian Sovdep was consistently hostile towards other parties belonging to the Military Revolutionary Committee due to the fact that they had demonstrated, contrary to the Vilnian Sovdep, loyalty to the Soviet Army [!]. The Vilnian Sovdep believed that, until the convention of the congress of all Lithuanian Sovdeps, the authority should belong to that in Vilnius. Therefore, the communists did not participate in the vote on the recognition of the Provisional Government, as they questioned the rationale behind voting on this matter.

\section{Attempts of Lithuanian communists towards the liberation of Lithuania}

The Soviet government of Lithuania resided in Dvinsk (modern-day Daugavpils). Prime Minister Mickevičius-Kapsukas preferred it to remain there, but only a minority supported his stance, and he was eventually outvoted by the supporters of the "return to the capital." On the first day of the deliberations of the Soviet Provisional Government (7 January), focus was placed on matters relating to the organisation of the Lithuanian army and the mutual relations between the Soviet Government and the Revolutionary Military Council. After consulting his Polish comrades, Stanisław Pestkowski spoke out in favour of transforming the War Revolutionary Military Council of the Western Front into a four-person board. This body was to obtain the same functions and privileges as those previously held by the Revolutionary Council of the Western Front. Interestingly, the board was to consist of a military director and three commissars: of Belarus, Lithuania and Poland.

In contrast, Vincas Mickevičius-Kapsukas considered it necessary to form an independent Lithuanian army, as well as the Military Council of Lithuania (or a politically and operationally autonomous section of the revolutionary War Soviet of the Western Front). Mickevičius's group dominated the session. Contrary to Gopner's expectations, the discussion on 7 January focused on the range of prerogatives of the future Lithuanian Military Council. Gopner decided to intervene. 
He reminded the participants that, by appointing the permanent Lithuanian representative in the person of Comrade Norvidas, the Revolutionary Military Council of the Western Front had excluded the necessity for the Soviet Government of Lithuania to express its opinions or to ask any questions. He stressed that, unlike in military matters, the Lithuanian government did not show any separatist tendencies in terms of financing, which it expected to obtain from the central authorities. He noted that only a few among the Lithuanian comrades had used the word "loan" instead of "subsidy," and that only comrades Mickevičius and Weinstein[Baranovski] contemplated retaining the taxes introduced by the Taryba.

Finally, Gopner diplomatically pointed out the need to divide military issues into two groups:

- operational and administrative matters decided in strict consultation with the central authorities, and

- organisational matters, which would include dissemination, recruitment, formation and food supplies.

The functioning of such an organisational group would be possible only in the case of an independent local body of any name, whose range of competencies was yet to be defined by the central authorities. Gopner stated that only then could this body be subsidised.

He considered the implementation of an agricultural reform necessary in order to enable the introduction of revolutionary taxes. He also believed that the imposition of wage brackets would be beneficial for the fiscal policy.

Gopner was surprised to find that "the course headed away from the central authorities" undertaken by his Lithuanian comrades was accompanied by the fact that, according to his observation, this "peasant country" had not displayed any revolutionary turmoil itself or taken part in the abolition of the authority of landowners and capitalists. He noted that "the Lithuanian peasants felt liberated not only from their masters, but also from any obligations towards the revolutionary authorities." Gopner also criticised the "procedure of selection of the cabinet" used during his absence. He openly stated:

it is as if those who have planned it are sentimentally stuck to the national principle. Nothing good will happen out of this charade. And now-friendly Moscow might be compelled, even against its will, to impose a subsidy in people. ${ }^{79}$

From Gopner's point of view, the problems of the Lithuanian government were due to the lack of personnel qualified to take up positions of responsibility (no appropriate candidates have been found for the positions of heads of a number of commissariats: for Justice, Health, Social Security and State Control), which, as he predicted,"would result in surrendering the helm to the Lithuanian socialists,

79 Gopner, 15 January 1919. 
who had already been asked to take up several responsible positions." Gopner recommended that the addressees of his report refrain from intervening until this "business" government, as he called it, would be complete, ${ }^{80}$ and requested a general purge ("once and for all"). Comrade Pestkowski, who advocated a strategy of small steps, disagreed. At its first meeting the government proclaimed a decree granting equal rights to all nationalities, and the declaration was entrusted to Pestkowski. As for the extremely innovative project of a decree on land prepared by a man named Wielski, Gopner was so strongly impressed by its content that he suggested that the authorities in Moscow should take notice of it.

Gopner warned that a prerequisite for Bolshevik success was not leaving Vilnius to its own devices. He did not consider Pestkowski a sufficient warrantor of Soviet rule in the city. "A few days alone in their capital without any communication with Moscow was sufficient for Lithuanians to display bourgeois-democratic, particularist and nationalist tendencies." ${ }^{81}$ Gopner contrasted the Lithuanian indolence with the zeal of the Belarusians, who had at their disposal the complete and sufficiently robust structures of the Regional Executive Committee of the Western Front, which remained operational throughout the entire revolution.

Noting that the Lithuanians were not ready to accept the new system of Soviet rule, Gopner informed Moscow bluntly:

\begin{abstract}
A breakthrough will be necessary to transform the rotten rivulets of the workers' movement in Lithuanian cities (and especially in Vilnius) into a navigable river and join the revolution. This primitive, independent cell must be immediately broken up and replaced with a universal organisation of the proletariat adequate to this era. The shaping of the Soviet Republic of Lithuania will not affect our international situation and therefore the further spread of the worldwide revolution and the defence of the occupied/conquered territory, but will also undoubtedly play a significant role in the class struggle within Lithuania, depriving the bourgeoisie of its last positions and tearing the powerful instrument of nationalist demagogy from its hands. ${ }^{82}$
\end{abstract}

80 The government was completed as follows: Mickevičius-Kapsukas (Prime Minister and Foreign Minister), Antanavičius (Minister of Interior), Cichowski (Minister of Finance and Agricultural Affairs), Dimanstein (Minister of Labour), Jakševičius (Minister of Transport), Proletaras (Minister of Communications), Biržiška (brother of arrested minister Taryba, Minister of Education), Weinstein (Minister of National Economy and Trade, also served as chairman of the Vilnian Revolutionary Committee and minister of the Revolutionary War Committee/Vilnian Revolutionary War Committee). In his report, Gopner dismissed the competences of Cichowski, Proletaras and Antanavičius ("too soft for internal affairs").

81 Gopner, 15 January 1919.

82 Ibid. 


\section{Gopner's information on the change in the political balance of power in Vilnius}

According to Gopner, the Lithuanian comrades "benefited from the total absence of sabotage on the part of the local intelligentsia of all nationalities," which, as Gopner concluded, "saved them a lot of effort." The intelligentsia of all nationalities that remained in Vilnius (specialists in state and economic management of all levels) had been, according to Gopner, stifled morally and physically "by the heel of the [German] occupier, and having in mind the experience of the Russian intelligentsia in Vilnius, they willingly applied for work in the Soviet offices of the Provisional Government of Lithuania." 83 According to him, the Vilnian political parties "vegetating between socialism and capitalism" were giving very weak signs of life. "And, above all, they did not show any signs of resistance to Soviet construction. Their adaptation to the current situation oscillated towards constructive opposition." ${ }^{4}$

Gopner undoubtedly remained in contact with "the worker masses of Lithuania, which showed strong political commitment to Russia," since he noted "in particular the attachment to the Russian language among the Jewish-worker milieus." He considered this phenomenon to be the result of

a rearrangement in the sphere of political influence, which almost completely wiped out the Labour Bund in the Lithuanian capital, where it had been brought to life and had grown for many years to become the leading political party among the Jews. The Bund used to be stronger than all the workers' organisations put together and dictated the tone to the entire Jewish workers' movement in Lithuania, Poland, Ukraine and Russia. After its left wing dissociated itself from the revolutionary process, its right wing drew the Bund towards the camp of the opponents of the socialist revolution. The Bund has broken off with the Jewish workers and now numbers 200 real and 250 fictional members in Vilnius. That reminds me of the years 1901-1903, the years of underground work, when, besides the members of the illegal labour unions joining the Bund, only one political organisation had about 1,000 members, and during the First Revolution (1905-07) the Bund in Vilnius was several thousand strong. The Jewish workers moved to the camp of revolutionary social democrats (?), which had historically formed as a Jewish political party. Its representatives were almost exclusively Russian communists. ${ }^{85}$

Gopner saw nationalism as "a reflection of underdeveloped class adversities." He warned that "until the decisive victory of socialism is achieved, nationalism will

${ }^{83}$ Count Wincenty Łubieński worked in the Presidium of the Council of Workers' and Red Army Deputies in Vilnius, All managerial positions at the Commissariat for Agriculture were occupied by Poles. Ludwik Chomiński, Tadeusz Niedzielski, Lubkowski, Zastowski, Zygmunt Ruszczyc and Kątkowski worked there. See: J. Gierowska-Kałłaur, Zarząd Cywilny Ziem Wschodnich, Warszawa 2003, p. 46.

${ }^{84}$ Gopner, 15 January 1919.

85 Ibid. 
penetrate into all crevices of society and seek to penetrate into the state organism and the main citadel of the Soviet Republic, the Communist Party of Lithuania." He wrote: "There are signs that cannot be explained by the changes of orientation of the bourgeois intelligentsia, which can be seen in the dangerous tendencies of many comrades, placed by the circumstances by the Soviet anvil in Lithuania." 86

He would set the Belarusian communists as an example for their Lithuanian counterparts. He quoted a document published in Minsk newspapers on 17 January:

"From the Central Bureau of the Communist Party of Bolsheviks of Byelorussia. In some localities of Byelorussia there have appeared individuals who call themselves Byelorussian communists and who have apparently set themselves the goal of Soviet work in those places. In most cases, these individuals are involved in nationalist agitation. The Central Bureau of the Communist Party of Bolsheviks of Byelorussia announces that the above-mentioned elements have nothing to do with communism or the party. Local comrades and the organisation are advised to have regard only to the agents of the $\mathrm{CB} \mathrm{KPb}$ of Byelorussia or the local committees of the Communist Party of Bolsheviks of Byelorussia." ${ }^{\prime 7}$

Gopner was of the opinion that the political condition of Lithuania "appeared to be extremely favourable for the organisation of Soviet rule." He drew attention to the fact that during the German occupation,

the news of victories and defeats brought about by the February and October revolutions reached the broad masses of peasants and workers in a distorted and exaggerated fashion. The more the occupying forces, bourgeoisie and social democrats were terrorising the people with misfortunes after October 1917, the more unanimous the counter-revolutionary block was becoming, persecuting the idea of the socialist revolution; the more the mystical elation and respect for the great process in the East was emerging in the soul of the workers' nation. Some unspeakable longing and persevering dreams took hold on the day of the sowing of slander against Soviet Russia, and usually gave rise to a significantly enhanced, purely illusory representation of the benefits of the Russian revolution. However, there is here an environment in which the poison of the social democratic propaganda [sic], as any other regularly consumed poison, has successfully harmonised in the counter-revolutionary music with the representatives of the Bund, the PolishLithuanian Mensheviks [sic] and the partisans of the PPS. They were joined on the eve of the German withdrawal from Vilnius by a choir aimed at persecuting communism and the Soviet government, composed of individuals morally bankrupt in Russia: the right wing of the left social revolutionaries. No matter how hard the enemies of the Soviet regime were trying, nothing came of these efforts and the red army was, without any "buts," warmly welcomed by the Lithuanian people. What is more, the leaders of the opportunistic camp of the Vilnian Lithuanian Council had only enough courage and reason to put forth some doctrinaire complaints. Due to the anti-parliamentary method of the formation of the Provisional Council of Lithuania and of the Vilnian War and Revolutionary Committee,

${ }^{86}$ Ibid.

87 Ibid. 
these complaints took place during the utmost boring ceremony of expressing loyalty to the new regime. ${ }^{88}$

\section{The moods in the Lithuanian countryside and cities in the eyes of David Yulevich Gopner}

In his report Gopner expressed the opinion that the moods among the peasants gave no reason for concern. In short, "they secure the regular course of Soviet construction." Gopner stated this based on his own observations. Together with other comrades, he travelled on horseback from Švenčionèliai (Nowe Święciany) to Vilnius and from Vilnius to Smorgon. "Through this wilderness, where the people had never heard anything other but the cracks of Tsarist or German whips." They travelled on a sleigh, incognito, not rectifying those who took them for merchants. According to his accounts, "in the dark houses illuminated by torches," he would listen to stories about the year... 1812 .

Gopner stated that many towns and villages were populated by Polonised Lithuanian Belarusians who called themselves Poles, but whom he called "yamshchiks." According to Gopner, all these "yamshchiks" were poor, ignorant, and religious. They were unaffected by either the nationalist agitation of "legionnaires," by the priests' agitation from the church pulpits and at homes, or by the material benefits associated with joining the legions. However, he drew attention to the distinctive fact that their criterion for self-identification was the language that they spoke, Polish.

He described a situation that he considered extremely characteristic. The "yamshchiks," seeing a sleigh with propaganda literature, asked for "prayer books" and could in no way understand that the newcomers did not have any. The arrivals [Gopner and the comrades pretending to be merchants] had to convince them that the legionnaires were the defenders of their masters and that the Russian soldiers, with whom they were constantly scared, and who were instead their brothers on equal terms, would bring Russian order and overthrow the landowners and various creditors. The "yamshchiks" approached these arguments with great reserve, and their main concern was the fact that priests would also be banished, and they could not imagine everyday life without their presence in temples.

Gopner referred to these peasants as "ignorants" and noted with dismay that they had already established municipal committees. He also noted that in the richer villages, where peasants had 8-12 dessiatins of land each, there was concern about whether the richer peasants would not lose their estates. There were no other questions. The peasants remembered the punishments that they had incurred for the refusal to provide volunteers to their "masters' army," a.k.a. "that

88 Ibid. 
band of legionnaires." Gopner only pointed out that the atrocities that these people had experienced during the German occupation had left a strong imprint in their minds, which would need to be given more attention in Russian propaganda through condemning German imperialism for its crimes. However, one should also be aware of the debt of gratitude owed to the Germans for the significant consequences of their actions in Lithuania, which could not be matched by any Soviet propaganda. The Germans warmed up the inhabitants of the former Grand Duchy of Lithuania to the Soviet ideas more effectively than the best Soviet propaganda could ever do.

The situation in the cities was different. Gopner described it very enigmatically: "Conditions favourable for the Soviet system are a lake into which various springs flow. Their stream is subject to smaller and greater changes."

The first reaction of the residents of Vilnius after the Soviet army entered the city was... an outburst of enthusiasm for freedom from German occupation. Gopner pointed out, however, that this joy would have been identical if it had been the Tsarist army that had taken the Germans' place. He concluded that this was due to the simple fact that "even the Tsarist regime did not manifest so much self-righteous authority over the entire population with no distinction of class or nationality as the Germans did." While stressing that he did not possess any information regarding the hardships experienced by the local bourgeoisie, either large or small, Gopner claimed that the overwhelming majority of the burden imposed by the occupation rested on the shoulders of the peasants. ${ }^{90}$ Therefore, he believed that "the current enthusiasm for the liberation from German occupation flows onto the flywheel of the revolution, but this is not stimulating for the latter. It does not lead to development nor does it provide security for the future. A horizontal network of political parties intersects in the cities: communists, all kinds of nationalists opportunistic to socialism, Polish-Lithuanian national democrats, Zionist Jews, etc." 91 As he summed up: "you would not find such a proletarian landscape of fragmentation of social branches and class ignorance anywhere in Russia." 92

\section{Gopner's remarks on the language issue}

Gopner was aware that "everyday work, revolutionary propaganda and the education of the people" required quick decisions with regard to language. When comparing the situation in Vilnius in 1904 with the present, Gopner stated that the Russian language was incomparably more important in Vilnius in 1919 than

${ }^{89}$ Gopner, 15 January 1919.

90 Aleksander Szklennik perceived the situation very differently. See: A. Szklennik, Wspomnienia o wydarzeniach $w$ Wilnie $i$ w kraju. Dziennik, comp. and prefaced by J. Gierowska-Kałłaur.

${ }^{91}$ Gopner, 15 January 1919.

92 Ibid. 
15 years earlier. ${ }^{93}$ However, he also noted that none of the five languages used by the Lithuanian population (Lithuanian, Jewish, Polish, Belarusian, Russian) could aspire to be the dominant one. He considered Belarusian and Polish to be the least known languages in the entire country, in contrast to Lithuanian in villages and Jewish in cities. He wrote: "people mainly speak Polish or Jewish in towns and cities, and Lithuanian or Byelorussian in the countryside, but with the exception of the most desolate corners of the country, the entire population understands and speaks Russian." ${ }^{24}$ Gopner believed that the common language in Lithuania was Russian, considered even by non-Russian nationalist elements to be neutral and not conducive to hostilities. He emphasised that the Polish community in Vilnius was not hostile towards the Russian language, as was the case in Warsaw.

\section{Gopner's remarks on education}

Gopner valued the importance of education in achieving the goals and the consolidation of Soviet rule in the controlled territories. He proposed to renounce "all quasi-academic claims of nationalists of all kinds about the cultural needs of one or another population group. All these scholars equipped with numbers and protocols written a long time ago, in the face of national persecution, political oppression and Russification in Russia and the policy of suppression in the Polish and Lithuanian provinces of Germany." ${ }^{" 5}$ He proposed to conduct a survey among the population, while rejecting any accusation that he was in favour of a referendum. He believed, however, "that unlike economic and political issues, where it was easy to differentiate between class interests, the matters of language and education had become so disorganised by bourgeois-democratic nationalism that it would be most appropriate [...] to appeal to the common sense of the working masses, and to their economic interests associated with school." At the same time, he suggested the creation of national commissariats and "the implantation of that or another language under the cover of historical, ethnographic or other research within the country." ${ }^{\prime 6} \mathrm{He}$ did warn however that any attempt to annihilate a language could lead to the very opposite effect. In order to avoid unpleasant surprises during the survey, he postulated "the removal from the vote of all non-labour elements, thus depriving the bourgeoisie of its positions, in which it protects its existence under the sauce of culture and education." 97

\footnotetext{
${ }^{93}$ Gopner's observation could both have been caused by the effects of the exodus of Vilnian Poles in fear of approaching Bolsheviks, or just be a simple consequence of the fact that Gopner had no contact with the Poles who had remained in Vilnius.

${ }^{94}$ Gopner, 15 January 1919.

95 Ibid.

96 Ibid.

97 Ibid.
} 
He advocated an equally tenacious policy aimed at eradicating the influence of the bourgeoisie, priests and rabbis on the adolescents. Before the planned referendum of workers and peasants he proposed to remind the voters that the interests of minorities would be respected and would not be subdued to the wishes of the majority. He predicted that the referendum "would rectify both the Russificators and the Polonisers, and bury the illusions of jargon lovers at Jewish schools." ${ }^{98}$ Gopner anticipated that a small minority in towns and cities would opt for Polish and Jewish schools, but in many towns and villages of eastern and southern Lithuania the population would vote for Lithuanian schools.

\section{Gopner's remarks on Vilnian periodicals}

Upon the capture of Vilnius by the Bolsheviks, seven newspapers in German, Lithuanian, Polish and Russian ceased to exist. On 15 January 1919, 10 daily newspapers were issued in Vilnius: three in Russian, three in Yiddish, two in Polish and two in Lithuanian. Four of them were described by Gopner as social democratic agencies (Lithuanian, Russian, Jewish, and Polish). He noted that some of the urban population preferred Russian publications and Russian-speaking orators. He wrote: "Neither the German occupation, nor the Polish-Lithuanian chauvinism, nor the enmity and fear of everything Russian that had been implanted during the occupation, have managed to eliminate the existence of the Russian press. During the occupation, no less than three Russian newspapers of various Russian groups were published in Vilnius. The displays of kiosks and bookshops in Vilnius were full of Russian-language books and magazines." He noticed that the Russian press "traditionally enjoyed high sales among the Polish population of Vilnius, but the Tsar's policy of Russifying the country by force encouraged hostility towards everything Russian." 99

He postulated that the newspapers published by those who loyally cooperated with the Soviet authorities not be suspended. The more so as supporters of the parties supporting these newspapers would consider such a move an unjustified restriction. Gopner stressed that the readers of these newspapers loyal to the new government had been uninformed at best, if not kept in a state of hibernation, for the previous dozen or so months. He believed that, in the society's mind, "there was no February or even October revolution where there would not be such a fierce party struggle that would make such an act psychologically understandable." 100

98 Ibid.

99 Ibid.

100 Ibid. 


\section{Gopner's remarks on economic affairs in Vilnius}

Gopner had always placed great focus on economic issues. Vilnius had never been a large industrial centre, yet before the German occupation, its production was not limited to local consumption, and was also exported. This resulted in the existence of a large proletariat in the city, employed in factories and craft workshops. There were especially many tanning factories, as the city was an important leather processing hub in the former Grand Duchy of Lithuania. According to Gopner, Vilnius had numerous fur warehouses, mechanical shoe factories, gloves and hosiery manufactories. Furthermore, there were several large envelope-producing plants, many printing houses, a robust brushmaking industry (bristles), a cigarette tube factory and several breweries (beer and mead). In addition to craft shops for the local market, Vilnius also boasted a large number of industrial plants producing clothing, underwear, hats and knitted fabrics for export. The town was a well-known and thriving centre for trade and business.

In his report of 15 January 1919, Gopner expressed several times his opinion that the final balance of the German occupation of Vilnius was tragic. Only scraps of food were left, and in addition to the stolen stocks, also all raw materials, fabrics and other components had been carried away. When retreating, the Germans damaged the transport infrastructure by taking away the entire railway stock and by burning all stations, bridges and buildings belonging to the railway network on all access roads to Vilnius. The situation was similar in half of the cities and towns in the controlled area. The region's other large centre of leather industry, Smorgon, was literally razed to the ground; the city was covered by a maze of trenches, as the front line had been passing right through it.

Gopner warned that it was almost certain that the other parts of Lithuania, which would soon get robbed of tools, fuel, metal, and machinery by the Germans before passing under Soviet administration, would be in even worse a condition than Vilnius. He concluded: "This will inevitably place the Soviet authorities before the immense challenge of organising the Lithuanian Republic's household on ruins, without machines and tools, without fuel or any metal to use."101 Gopner compared the German invasion of this territory with the Plagues of Egypt and believed that after such an experience it would be unwise to impose nationalisation and workers' control. All the more so as "the jackals of speculation and enrichment have long since secured whatever the Germans had missed in their robbery." Gopner simply considered it a pointless waste of energy to develop special structures aimed at recovering the negligible leftovers from the German occupation.

In order to lift the city from complete economic ruin, he called for an immediate end to speculation on the Russian ruble. He also insisted on accelerating railroad works, not only for strategic reasons. Vilnius was close to an alimentary

101 Ibid. 
crisis because of the impossibility of supplying food. Despite the objective circumstances, he wrote, it was clear that some specific benefits were expected from the new government. In order to meet these expectations, Gopner believed it was necessary to hasten the replacement of the tracks from the Vilnius station to the east, which had already begun on 12 January $1919 .{ }^{102}$ An interesting piece of information is that, at the first meeting of the Soviet Lithuanian government (7 January 1919), Weinstein reported that, owing to the efforts of "that part of the government that resided in Vilnius," the recruitment of workers for railroad work had begun even before the Germans had left, i.e. in December 1918. It was made possible by "the very same comrades who, during the strike at the railway enterprise, had acted as an organ of the Provisional Government and assigned 250,000 marks to the organisation of the strike." 103

Gopner outlined the following work plan: the primary task was to prepare information for the Superior Board of the People's Economy (Vysshiy sovet narodnogo khozyaystva, VSNKh). In his opinion, this was a prerequisite for the preparation of concrete proposals and orders by the Board. Determining the city's employee potential did not seem to pose a problem to him, but some difficulty would be the identification of industrial needs. He deemed it necessary to establish industry in Vilnius based on local raw materials. He considered it a priority to define raw material resources in a way that would allow to define the scope of both supply and exchange of materials between the recovering Lithuanian economy and Russia. It follows from his text that the self-sufficiency of the Lithuanian state was envisaged only in terms of food supply. As Gopner pointed out, "Lithuania is able to feed itself [...] obstacles will be many, but we may not worry about them; if the greater part of the Vilnius Governorate is in need of food supplies, then the remaining parts of the Kovno Governorate (the Šiauliai, Raseiniai and Panevežys counties, considered to be the leading ones) will have to produce them." 104

Gopner believed that the Germans had done everything they could "to starve the country to death." The farms in the countryside looked miserable; all the villages visited by Gopner shared the same fate: only a couple of houses even had a cow. Only some of the villagers were able to purchase the most haggard horses at exorbitant prices, and the entire livestock was completely ruined anyway. The retreating Germans not only took with them the swine and poultry, but even the meat from already slaughtered animals. They also severely punished the locals for hiding fresh, yet unprocessed skins. Only a handful of people, the cleverest

102 With particular regard to the sections Vilnius-Solas and Vilnius-Dvinsk. Gopner meticulously noted that from the Rokiškis station onwards all railway infrastructure, including bridges, had been destroyed by the retreating Germans.

103 Gopner, 15 January 1919; P. Łossowski (op. cit., p. 29) cites a quote from: F. Ł-i, "Kolejarze wileńscy w akcji odzyskania Wilna dla Polski," in: Wilno wyzwolone. Jednodniówka na zjazd byłych uczestników walk o Wilno w dniach 10-11 listopada 1930, Wilno, 1930, p. 33.

104 Gopner, 15 January 1919. 
ones, managed to conceal some minimum reserves, but in general there was no grain for sowing. There were no winter grains either, since the Germans had forbidden field works in order to engage the peasants in road works and in demolishing damaged buildings to use the recovered stone to pave the roads. The only beneficial remnant of the German occupation was road infrastructure. They survived simply because it was impossible to steal them.

The manors of the landed gentry were in no better condition, but the landowners had managed to hide some of their property and therefore the estates were guarded by municipal committees in order to protect them from attacks. Huge stretches of forest were cut down, but the forest estates survived.

Anticipating a rapid military operation in Lithuania, Gopner believed that "Lithuania would be cleared by the end of February." Gopner was filled with optimism and, given the rational and calm attitude of the Lithuanians and their penchant for discipline, predicted a painless and vigorous process of organisation of Soviet power even before the sowing season.

He conveyed to Moscow the opinion prevailing in Vilnius that the establishment of the "people's economy" would have to be conducted in a different way than the one applied so far in Soviet Russia. He expressed his opinion very categorically: "No one needs blind imitation, especially of foolishness and mistakes. The first experience with the organisation of socialist agriculture should not lead to these risky conclusions of breaking with the masses." [...] "Carefulness and criticism-yes, revision-no." 105

\section{Gopner's remarks on trade and crafts}

Gopner opted for keeping trade and crafts in private hands. He believed that the private trade network could be cleverly exploited when controlled with a firm hand. He was aware that eliminating private trade would be

as throwing the baby out with the bathwater, instead of securing the needs for food supply and exchange. As long as all of our organisations lack experience and wisdom of the bourgeoisie, we will be bound to pay a tribute to our predecessors for their tacit mediation. Otherwise, instead of specialists, we will have miserable amateurs or Soviet specialists dissatisfied with their salaries, prone to sabotage and corruption. ${ }^{106}$

Gopner proposed a completely different policy for the recovering branches of Lithuanian industry.

Unlike in trade and crafts, private entrepreneurs should not be tolerated any longer in industry. Separate professional companies should be organised into industrial syndicates.

105 Ibid.

106 Ibid. 
All possible efforts should be undertaken in order to revitalise every branch of industry by concentrating it, preventing the return of the artels, while avoiding the alienation of the technical personnel. In my private conversations with Lithuanian comrades, I have observed revisionist tendencies. Revision of Russian practice in such a way as to encourage subcontractors to cooperation or even to temporarily leave the capitalists and specialists in their current positions is absolutely unjustified and should not tempt Lithuanian comrades. ${ }^{107}$

\section{Conclusions}

The content of the discussed documents, produced by authors representing both opposing sides of the front, allow us to reach a conclusion in the discussion on the starting point of the Polish-Bolshevik War. Undoubtedly, it was 4 January 1919.

David Yulevich Gopner's report provides unique information not only on the thorough and total deprivation of Lithuania by the retreating Germans of all goods that could be removed. The document contains a comparison of the state of Vilnian industry in 1904 and 1919 and, above all, a report on the changes in the balance of political forces in the city, at least those that were apparent to the representative of the central Soviet authorities in the conquered territory. Gopner also notes the growth of Social Democracy at the expense of the Labour Bund.

David Yulevich Gopner's report is not only an invaluable testimony to the birth of a new system of power in the territory of the former Grand Duchy of Lithuania, but it also provides a comprehensive description of the reality in the Lithuanian countryside and cities at the time when the Bolsheviks seized these territories. The landscape is devoid of even a hint of revolutionary turmoil. One interesting element is the portrayal of the dominant views among the different groups of Lithuanian communists and the details of the struggle between nationalists and federationists, between collaborators of the Bolshevik authorities and those who arrived along with them. Gopner's report also constitutes an important source of information on the degree of identitary awareness of the inhabitants of the former Grand Duchy of Lithuania (Polish-speaking "yamshchiks").

The mentions of the "fiercest red Polish-Lithuanian units" are straight fascinating, as are the revelations about "Polish-Lithuanian national-democratic parties," "Polish-Lithuanian Mensheviks" or "Polish-Lithuanian chauvinism."

\section{Bibliography}

Deruga A., Polityka wschodnia Polski wobec ziem Litwy, Białorusi i Ukrainy (1918-1919), Warszawa, 1969.

Gierowska-Kałłaur J., „Depozyty” Walerego Sławka przechowywane w Moskwie. („Biuro Detaszowane Oddziału II Naczelnego Dowództwa 1919”), „Studia z Dziejów Rosji i Europy Środkowo-Wschodniej" 47, 2012, pp. 208-272.

107 Ibid. 
Gierowska-Kałłaur J., Polacy z guberni pótnocno-zachodnich (białoruskich) wobec idei odbudowy niepodległej Polski oraz białoruskich idei niepodległościowych. Polacy na Białorusi od końca XIX do początku XXI wieku, vol. 2, ed. Tadeusz Gawina, Warszawa, 2018.

Gierowska-Kałłaur J., "Stanisław Bułak-Bałachowicz. Postać, która mogła połączyć narody byłego Wielkiego Księstwa Litewskiego, a jednak ich nie połączyła," Acta Baltico-Slavica, 41, 2017, pp. 77-155.

Gierowska-Kałłaur J., preface to: A. Szklennik, Wspomnienia o wydarzeniach $w$ Wilnie i $w$ kraju. Dziennik, part 1, comp. by J. Gierowska-Kałłaur, in: Metamorfozy społeczne, vol. 18, Warszawa, 2018, pp. 7-37.

Gierowska-Kałłaur J., Zarząd Cywilny Ziem Wschodnich, Warszawa, 2003.

Gierowska-Kałłaur J., “Żydzi i Polacy na Wileńszczyźnie w latach 1919-1920,” in: Świat NIEpożegnany. Żydzi na dawnych ziemiach wschodnich Rzeczypospolitej w XVIII-XX w., ed. K. Jasiewicz, Warszawa-Londyn, 2004.

Gierowska-Kałłaur J., "Wpływ zmiany okupanta na miejską wielonarodowościową społeczność. Przypadek Wilna w latach I wojny światowej," in: Gorad i âgo žyhary: portrèt na fone èpohì. X-XX stst., ed. A. F. Smalenčuk, Mìnsk, 2016.

Jurkiewicz J., Rozwój polskiej myśli politycznej na Litwie i Białorusi w latach 1905-1922, Poznań, 1983.

Łossowski P., Konflikt polsko-litewski 1918-1920, Warszawa, 1996.

Michaluk D., Białoruska Republika Ludowa 1918-1920. U podstaw białoruskiej państwowości, Toruń, 2010.

Rezmer W., "4 stycznia 1919 roku - początek wojny Polski z Rosją Sowiecką," Przegląd Historyczno-Wojskowy, 2009, no. 1, pp. 55-68.

Rezmer W., "Начало польско-советской войны 1919-1920 гг.: исследовательский вопрос," in: Чичеринские чтения. Россия и мир после первой мировой войны (К 90-летию окончания войны и подписания послевоенных соглашений). Материалы международной научной конберениии 11-12 ноября 2008 г., Тамбов, 2009, рр. 266-281.

Rezmer W., “Когда и почему началас война между Польшей и Советской Россий? Историография вопроса," in: Россия и Польша: долг памяти и право забвения (Москва, 22-24 октявря 2009 г.). Тезисы докладов, Москва, 2009, р. 76.

Wyszczelski L., Wojna polsko-rosyjska 1919-1920, vol. 1, Warszawa, 2010.

Joanna Gierowska-Kałłaur, dr hab., professor at the Institute of History of the Polish Academy of Sciences and the Centre for East European Studies, University of Warsaw. Author of, among others: Straż Kresowa a Zarząd Cywilny Ziem Wschodnich. Wspótdziałanie czy rywalizacja? (Warszawa, 1999), Zarząd Cywilny Ziem Wschodnich (19 lutego 1919 - 9 września 1920) (Warszawa, 2003), Raporty Straży Kresowej 1919-1920. Ziem Pótnocno-Wschodnich opisanie (Warszawa-Pułtusk, 2011). Research interests - the fate of the inhabitants of the former Grand Duchy of Lithuania in the First World War and the Polish-Soviet War. 